E3S Web of Conferences 1, 16001 (2013)

DOI: $10.1051 / \mathrm{e} 3 \operatorname{sconf} / 20130116001$

(c) Owned by the authors, published by EDP Sciences, 2013

\title{
Contamination and risk assessment of heavy metals in bottom sediments from Lake Valencia, Venezuela
}

\author{
A. González ${ }^{1}$, M. G. Palma ${ }^{1}$, K. Ziegler ${ }^{1}$, E. González ${ }^{2}$ and M. A. Álvarez ${ }^{1 *}$ \\ ${ }^{1}$ Centro de Química Analítica, Facultad de Ciencias, Universidad Central de Venezuela, Caracas 1041-A, Venezuela, \\ *maria.alvarez@ciens.ucv.ve \\ 2 Instituto de Biología Experimental, Facultad de Ciencias, Universidad Central de Venezuela, Caracas 1041-A, Venezuela, \\ ernesto.gonzalez@ciens.ucv.ve
}

\begin{abstract}
The contamination and risk assessment of heavy metals in the bottom sediments of the Lake Valencia, Venezuela, was performed by determining the Enrichment Factor (EF), the Geoaccumulation Factor (Igeo), the availability of metals and the Risk Index Code (RAC). The sediments were anthropogenic ally enriched with $\mathrm{Pb}, \mathrm{Zn}$, $\mathrm{Cu}$ and $\mathrm{Cr}$ and classified as uncontaminated to moderately contaminated, with a medium risk of $\mathrm{Zn}, \mathrm{Co}, \mathrm{Ni}$ and $\mathrm{Cr}$, and low risk of $\mathrm{Cu}, \mathrm{Pb}$ and $\mathrm{Cd}$. Analysis of correlations and PCA showed temporal variations in the concentration of metals in the sediments during the rainy season, and spatial variations, where the depth and anthropogenic inputs are the main variables. The contamination of sediments was located on the axis connecting the mouths of the river Guayos, which crosses the city of Valencia, and the river Güey which crosses the city of Maracay, both highly industrialized. Although the concentration of dissolved heavy metals into the waters was within the regulations, important concentrations of $\mathrm{Pb}$ and $\mathrm{Hg}$ and the bioaccumulation of $\mathrm{Hg}$ and $\mathrm{Cr}$, determined by the Bioconcentration Factor (BCF), were found in the fish tissues which indicate that the metal enrichment of the lake sediments is affecting the biota.
\end{abstract}

Keywords: Heavy metals, available fraction, risk assessment, sediments, contamination, Lake of Valencia.

\section{Introduction}

The Lake Valencia, Venezuela, is the biggest natural fresh water lake in the country. It is located between the cities of Valencia and Maracay, important industrial, agricultural and urban centers, with high growth during the last decades. Sewage and waste from antropic activities are introduced into the lake by the tributaries and runoff affecting its environmental status. Studies in the area have reported the enrichment of bottom sediments of the lake (Mogollon and Bifano, 1993, 1996) as well as its waters and biota (MARNJICA, 2001) with heavy metals. The information on the environmental condition of the lake has not been updated in the last decade.

\section{Materials and Methods}

\section{Studied area}

Lake Valencia is located in north-central Venezuela (Fig. 1), between $67^{\circ} 07$ 'and $68^{\circ} 12^{\prime}$ west longitude, and $09^{\circ} 57$ 'and $10^{\circ} 26^{\prime} \mathrm{N}$ north latitude. Currently, the lake covers an area of $344 \mathrm{~km}^{2}$, an average depth of 19 meters and a maximum depth of 39 meters (González de Juana, 1980).

\section{Sampling}

Sampling was conducted at five stations (E1, E2, E3, E4 and E5), selected considering the industrial, urban and agricultural activities around the lake (Fig. 1). The sediments were collected from June to October, 2009, using an Ekman dredge. Water samples, at the surface and close to the sediment, using a van Dorn bottle, and fish (Oreochromis mossambicus and Hoplias malabaricus) were also collected from June 2009 to May 2010. The sampling was conducted bimonthly.

\section{Samples treatment}

The sediments were subsequently sieved in wet, dried at room temperature, and brought into solution following the standard procedure EPA 3052 to determine the total concentration of the elements. The sequential extraction procedure BCR-modified (Rauret et al., 1999) was employed to determine the chemical fractionation of the 


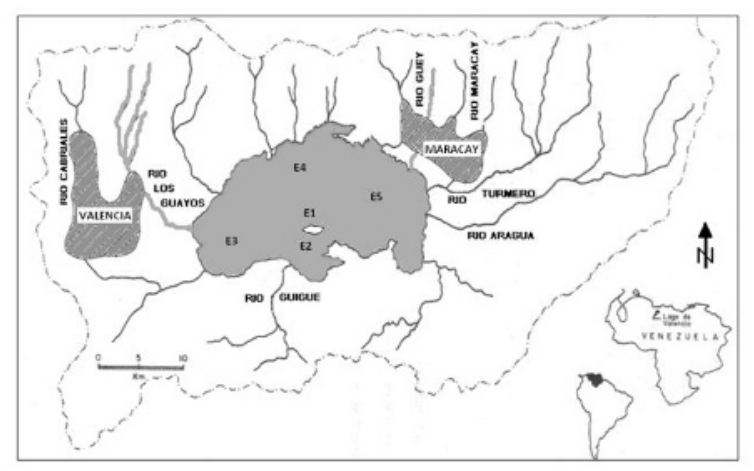

Fig.1 Location map and sampling stations at Lake Valencia

elements in the sediments. Water samples were filtered $(0.45 \mathrm{~mm})$ and adjusted to $\mathrm{pH}<2$ with $\mathrm{HNO}_{3}$. The fish were dissected to obtain the muscle and liver samples, which were lyophilized and digested using $\mathrm{HNO}_{3}$ and $\mathrm{H}_{2} \mathrm{O}_{2}$ and a microwave digester.

\section{Chemical analysis}

In the sediment samples were determined: $\mathrm{Al}, \mathrm{Si}, \mathrm{Ca}$ and $\mathrm{Mg}$ by atomic absorption spectrometry (FAAS); $\mathrm{Cd}, \mathrm{Cr}, \mathrm{Cu}$, $\mathrm{Ni}, \mathrm{Pb}, \mathrm{Zn}, \mathrm{Co}, \mathrm{V}, \mathrm{Fe}, \mathrm{Ti}$ and $\mathrm{Mn}$ by inductively coupled plasma atomic emission spectrometry (ICP-OES); and TOC using an elemental analyzer. $\mathrm{Cd}, \mathrm{Cr}, \mathrm{Cu}, \mathrm{Ni}$ and $\mathrm{Pb}$ by electrothermal atomic absorption spectrometry (ET AAS) were determined in water samples and fish tissue. The determination of $\mathrm{Hg}$ in all the samples was performed by cold vapor atomic fluorescence spectrometry (CV-AFS). The accuracy and precision of the methodologies applied were determined using certified reference samples of sediment (LKSD-4 and BCR-701), oyster tissue (NIST $1566 \mathrm{~b})$ and bovine liver (BCR-185R).

\section{Results and Discussion}

\section{Composition of the sediments}

The $98 \% \mathrm{w} / \mathrm{w}$ of the sediments collected corresponded to silt and clays $(<63 \mu \mathrm{m})$. The TOC concentration in the sediments was high $(10 \pm 4 \% \mathrm{w} / \mathrm{w})$ suggesting a strong antropic intervention. The concentration of the elements $\mathrm{Al}$, $\mathrm{Si}, \mathrm{Ca}, \mathrm{Mg}, \mathrm{Fe}, \mathrm{Ni}, \mathrm{Co}$ and $\mathrm{Cd}$ was comparable to the baseline values for Lake Valencia (Mogollon and Bifano, 1996), considering that these correspond to lithology contribution. In almost all stations, the concentrations of the elements $\mathrm{Pb}, \mathrm{Zn}, \mathrm{Cu}, \mathrm{Cr}$, Ni and $\mathrm{Mn}$ were higher than those of baseline. According to the EF (Gonçalves et al., 1992; Sutherland, 2000) and the Igeo (Muller G., 1969; Loska et al., 2004), determined using baseline values for Lake Valencia, the sediments were anthropogenically enriched with $\mathrm{Zn}, \mathrm{Pb}, \mathrm{Cu}$ and $\mathrm{Cr}$ (EF> 1.5) and were classified as moderately contaminated to uncontaminated $(0<$ Igeo $<1)$. The metallic enrichment showed differences between stations, observing the enrichment with $\mathrm{Pb}, \mathrm{Zn}$ and $\mathrm{Cu}$ in
$\mathrm{E} 1$, with $\mathrm{Zn}$ and $\mathrm{Cr}$ in $\mathrm{E} 2$, with $\mathrm{Pb}$ and $\mathrm{Zn}$ in $\mathrm{E} 3$, with $\mathrm{Zn}$ in $\mathrm{E} 4$, and with $\mathrm{Pb}, \mathrm{Zn}, \mathrm{Cu}$ and $\mathrm{Cr}$ in $\mathrm{E} 5$.

\section{Distribution of the metallic content of sediments}

The multiple correlation analysis showed significant correlations $(\mathrm{p} \leq 0.05)$ between the elements $\mathrm{Al}, \mathrm{Ca}, \mathrm{Si}$ and $\mathrm{Mg}$, reflecting the mineralogical composition of sediments, carbonates and clays, specifically smectites and chlorites (González de Juana, 1980), and between the elements Ti, Fe, $\mathrm{Co}, \mathrm{Cr}$ and $\mathrm{Cd}$. In the deeper stations (E1, E4 and E5) significant correlations between TOC and $\mathrm{Hg}$, and between these and the elements $\mathrm{Zn}, \mathrm{Pb}$ and $\mathrm{Cu}$ were found, indicating that the introduction of these elements into the lake sediments could occur together, either with the organic matter and/or by its precipitation due to the reducing conditions found in the bottom of the deeper stations.

Results from principal component analysis (PCA) showed spatial variations in the composition of the sediments, which are determined by the depth, represented by the Component 1 (29.6\% of PCA), and the anthropogenic input, represented by the Component 4 (9.5\% PCA) (Fig. 2). Depth is the variable determining the reducing and anoxic conditions in the deeper stations (E1 and E5), where together with the high levels of TOC and alkalinity produce the precipitation of the easily reducible elements: $\mathrm{Hg}, \mathrm{Cu}$, $\mathrm{Zn}$ and $\mathrm{Pb}$.

The Component 4, associated with the anthropogenic input of $\mathrm{TOC}, \mathrm{Hg}, \mathrm{Zn}, \mathrm{Pb}, \mathrm{Zn}$ and $\mathrm{Cu}$, was attributed to the discharge of the rivers Caño Central and Los Guayos, which cross the city of Valencia, and Guey and Aragua rivers that cross the city of Maracay, and their surroundings, this would explain the contamination of the sediments located on the axis connecting the stations E3, E1 and E5.

Temporal variations, identified by the Component 3 (15.3\% of PCA) (Fig. 3), occur during the rainy season when the concentrations of $\mathrm{Ca}, \mathrm{Mg}$ and $\mathrm{Mn}$ increase by its precipitation from the water as carbonates, due to the consequent increase of the $\mathrm{pH}$ of the waters by loading of sediment and nutrient to the lake, well as the Cinorg related to the carbonate lithology, represented by the Component 2 (22.4\% of PCA) (Fig. 3).

The elements: $\mathrm{Fe}, \mathrm{Cr}, \mathrm{V}$ and $\mathrm{Ti}$ were not grouped in any of the seven principal components determined $(93,6 \%$ of variability), indicating that their concentration in the sediments is mainly due to the lithogeochemical contribution.

\section{Chemical fractionation, mobility and availability of metals in the sediments}

The exchangeable or available fraction of metals (water soluble, inter-changeable and carbonate-associated elements) from the sediments showed elevated levels of $\mathrm{Ca}$, $\mathrm{Mg}$ and $\mathrm{Mn}$, reflecting the carbonate lithology nature of the area. According to the concentrations of the metals in this fraction, the mobility and availability of the elements presented the following order: $\mathrm{Zn}>\mathrm{Co}>\mathrm{Ni}>\mathrm{Cr}>\mathrm{Cd}>\mathrm{Pb}>$ $\mathrm{Cu}$. The available concentration of the elements varied 
between stations, being the highest values of $\mathrm{Zn}, \mathrm{Ni}, \mathrm{Cd}$ and $\mathrm{Co}$ in the stations E1 and E5, and that of $\mathrm{Cr}$ in the E3, while that of $\mathrm{Pb}$ was fairly homogeneous between stations.

As stated by the Risk Index Code (RAC) (Perin et al., 1985), determined by the available fraction of the element, the sediments from the west of the lake (E3) showed a high risk of $\mathrm{Cr}(31<\mathrm{RAC}<50)$; those from the south (E2) and east (E5) showed a medium risk of $\mathrm{Zn}$, Co and $\mathrm{Ni}$ (11 $<$ RAC <30); and in the center of the lake (E1) the sediments showed a medium risk of $\mathrm{Co}$ and $\mathrm{Zn}$. A low risk of $\mathrm{Cu}, \mathrm{Pb}$ and $\mathrm{Cd}(1<\mathrm{RAC}<10)$ was determined in the sediments from all the sampling stations.

Given the significant correlations determined between the elements $(p \leq 0.05)$, the source of the enrichment of $\mathrm{Cu}$, $\mathrm{Cr}, \mathrm{Pb}, \mathrm{Ni}$ and $\mathrm{Zn}$ may be associated with the runoffs of chemical pesticides and fertilizers from agricultural zones, as well as wastes from industries involved in paper, pigments, dyes and different foods industries, including beer; $\mathrm{Cd}, \mathrm{Pb}$ and $\mathrm{Ni}$ would be associated to waste power battery (Forstner et Wittmann, 1981).

Recent studies in the Suata reservoir, which receives water from the Rio Aragua before emptying into Lake Valencia, have also shown contamination of its bottom sediments with $\mathrm{Ni}, \mathrm{Cd}, \mathrm{Cr}$ and $\mathrm{Co}$ and signs of bioaccumulation of $\mathrm{Hg}$ and $\mathrm{Ni}$ in the liver of fish caught (Alvarez et al., 2012).

The metallic enrichment found in the bottom sediments from Lake Valencia is consistent with previous results (Mogollon and Bifano, 1993, 1996; MARN, 2001). Unfortunately, it was not possible to determine the variation of the enrichment over time, due to the use of non-standard methods to determine the levels of metal enrichment and the exchangeable fraction in the work of these authors.

\section{Waters}

According to the values of: $\mathrm{pH}$ : 8.4-9.6; $\mathrm{T}$ : $26.2-32.4{ }^{\circ} \mathrm{C}$; dissolved oxygen: 0-17.5 $\mathrm{mg} \mathrm{L}^{-1}$; conductivity: $1874-1942$ $\mu \mathrm{S}$ cm-1; ammonium: 33-1308 $\mathrm{mg} \mathrm{L}^{-1}$; hardness: 444-470 $\mathrm{mg} \mathrm{L} \mathrm{L}^{-1}$; and phosphates: 263-1052 $\mathrm{mg} \mathrm{L}^{-1}$, the lake is classified as hypertrophic.

Results obtained by multiple correlation analysis showed seasonal variations on the concentration of the dissolved metals in the waters of the lake, observing a decrease in the concentration during the rainy season, which is attributed to the increase in $\mathrm{pH}$ that occurs at this time. Throughout the year, the content of dissolved metals in the waters of Lake Valencia did not exceed the maximum values specified in the national and international regulations (Decreto 3219, 1999; EPA, 2006). Spatial homogeneity of the concentration of the dissolved metals in the waters of the lake were also found, both among sampling stations and within the water column, which is attributed to the continuous mixing of waters by the wind.

The annual average concentration of dissolved metals in the waters of Lake Valencia was: $\mathrm{Cd} 0.06 \mu \mathrm{g} \mathrm{L}^{-1}$; $\mathrm{Cr} 0.86 \mu \mathrm{g}$ $\mathrm{L}^{-1}$; $\mathrm{Cu} 0.57 \mu \mathrm{g} \mathrm{L}^{-1} ; \mathrm{Hg}_{0} 0.08 \mu \mathrm{g} \mathrm{L}^{-1}$; Ni $1.96 \mu \mathrm{g} \mathrm{L}^{-1}$; and $\mathrm{Pb}$ $1.18 \mu \mathrm{g} \mathrm{L}^{-1}$.

\section{Fish Tissues}

The average concentration of metals in the liver of Oreochromis mossambicus and Hoplias malabaricus was higher than in the muscle. The concentrations of $\mathrm{Cd}$ and $\mathrm{Cu}$ in the muscle of fish were within the national regulation (COVENIN, 1998), while those of $\mathrm{Pb}\left(0.2\right.$ to $\left.1.7 \mathrm{mg} \mathrm{kg}^{-1}\right)$ and $\mathrm{Hg}\left(0.02-0.39 \mathrm{mg} \mathrm{kg}^{-1}\right)$ were higher. Considering the Bioconcentration Factor (BCF) (OEHHA, 2000), there are indications of $\mathrm{Hg}$ bioaccumulation $(\mathrm{BCF}=14)$ and $\mathrm{Cr}(\mathrm{BCF}$ $=12$ ) in some specimens of fish caught, which would indicate that anthropogenic enrichment of the lake sediments could be affecting the biota.

\section{Conclusions}

The bottom sediments of Lake Valencia are enriched with TOC, $\mathrm{Zn}, \mathrm{Pb}, \mathrm{Cu}, \mathrm{Ni}, \mathrm{Cr}$ and $\mathrm{Cd}$. The metal contamination would be reaching the lake through the discharge of its tributaries, rivers Guey and Los Guayos, which carries the urban and industrial wastes from the large cities and industrial centers of Valencia and Maracay, as well as from the runoffs from agriculture activities. The metal contamination is retained in the bottom sediments and its desorption is not favored due to the alkaline $\mathrm{pH}$ of the water. Thus, the concentration of dissolved metals into the waters of the lake is within the regulations. However, evidence of bioaccumulation of $\mathrm{Hg}$ and $\mathrm{Cr}$ determined in fish tissues, show that metal enrichment of the sediments is reaching to the biota.

\section{Acknowledgements}

The authors thank the CDCH of the UCV (PG 03-00-64952006).

\section{References}

Alvarez MA, Aru R, Barrero M, González E, González Y, Sepúlveda G. Biogeochemical study of the Suata reservoir, Venezuela, according to the metallic content of their bottom sediments, water and fish. ACI 2012; 3 : 103-114.

Decreto 3.219. Normas para la clasificación y control de la calidad de las aguas del de la cuenca del Lago de Valencia. Gaceta Oficial Extraordinaria 5305. 1999

Forstner U, Wittmann GTW. Heavy metal pollution in the aquatic environment, $2^{\text {nd }}$ Ed. Spring-Verlag, Berlin, Heidelberg, New York. 1981.

Gonçalves E, Boaventura R, Mouvet C. Sediments and aquatic mosses as pollution indicators for heavy metals in the Ave river basin (Portugal). Sci. Total Environ. 1992; 114: 7-24.

González de Juana C.; Ituralde J, Picard X. Geología de Venezuela y sus Cuencas Petrolíferas. Foninves, Caracas 1980.

Loska K, Wiechula D, Barska B, Cebula E, Chojnecka A. Assessment of arsenic enrichment of cultivated soils in Southern Poland. Pol. J. Environ. Stud. 2003; 12: 187-92. 
MARN. Concentración de metales pesados en aguas, sedimentos, tejido muscular, hígado y vísceras de peces del Lago de Valencia, Estado. Aragua. Ministerio del Ambiente y de los Recursos Naturales. 2001.

Mogollón JL, and Bifano C. Mobil Metallic elements in a urbanized tropical catchment Lake Valencia, Venezuela. Chem. Geol. 1993; 107: 431-434.

Mogollón JL, and Bifano C. Geochemistry and anthropogenic inputs of metals in a tropical lake in Venezuela. Appl. Geochem. 1996; 11: 605-616.

Muller G. Index of geoaccumulation in sediments of the Rhine River. J. Geol. 1969; 2: 109-118.

Norma venezolana COVENIN 1087. Sardinas en conserva, 5ta Revisión. 1998.

OEHHA. Technical support document for exposure assessment and stochastic analysis. Apendix H, Fish Bioconcentration Factors. 2000.
Perin G, Craboledda L, Lucchese M, Cirillo R, Dotta L, Zanetta ML, Oro AA. Heavy metal speciation in the sediments of northern Adriatic sea. A new approach for environmental toxicity determination. In: Lakkas TD Editor. Heavy Metals in the Environment, Vol. 2. CEP Consultants, Edinburgh. 1985.

Rauret G, Lopez-Sanchez JF, Sahuquillo A, Rubio R, Davidson C, Ure A, Quevauviller Ph. Improvement of the BCR three step sequential extraction procedure prior to the certification of new sediment and soil reference materials. J. Environ. Monit. 1999; 1: 57-61.

Sutherland RA, Bed sediment-associated trace metals in an urban stream Oahu, Hawaii. Environ. Geol. 2000; 39: 611-627.

United States Environmental Protection Agency (EPA). National Recommended Water Quality Criteria. 2006. 